CAEP • Canadian Association of
Emergency Physicians
ACMU • Association canadienne
des médecins d'urgence

Canadian Journal of Emergency Medicine Journal canadien de la médecine d'urgence

EDITOR-IN-CHIEF / RÉDACTEUR EN CHEF

Grant Innes, MD

University of British Columbia, Vancouver

SEnior Associate Editors / RÉdacteurs ADJOINT

James Ducharme, MD

Dalhousie University, Saint John, NB

Riyad B. Abu-Laban, MD, MHSc

University of British Columbia, Vancouver

Managing Editor / RédaCtrice administrative

Penelope Gray-Allan, BA, BSc

cjem@caep.ca

ASSOCIATE EDITORS / RÉDACTEURS ASSOCIÉS

EM ADVANCES (original research)

Jacques S. Lee, MD, University of Toronto, Toronto

Ian G. Stiell, MD, MSc, University of Ottawa, Ottawa

Christian Vaillancourt, MD, MSc, University of Ottawa, Ottawa

CJEM JOURNAL CLUB

Michael J. Bullard, MD, University of Alberta, Edmonton

Eddy S. Lang, MD CM, McGill University, Montréal

CASE REPORTS

Anthony S. Taylor, MD, University of Calgary, Calgary

Community EM

David Mann, MD, Powell River General Hospital, Powell River, BC

Methodology: THE SCIENCE OF EM

Andrew Worster, MD, MSc, McMaster University, Hamilton, Ont.

PHARMACOTHERAPY

Peter J. Zed, BSc(Pharm), PharmD, Dalhousie University, Halifax, NS

Jeff Eppler, MD, Kelowna General Hospital, Kelowna, BC

ED AdMINISTRATION

Christopher M.B. Fernandes, MD, McMaster University,

Hamilton, Ont.

Marc Afilalo, MD, McGill University, Montréal

EDUCATION

Jason R. Frank, MD, MA (Ed), University of Ottawa, Ottawa

StATE OF THE ART (review articles and topical updates)

Jeffrey R. Brubacher, MD, University of British Columbia,

Vancouver

ToXICOLOGY

Roy Purssell, MD, University of British Columbia, Vancouver

CONTROVERSIES (issues and commentaries)

Jeffrey Freeman, MD, University of Michigan, Ann Arbor, Mich.

PEDIATRIC EM

Lance Brown, MD, Loma Linda University Medical Center and Children's Hospital, Loma Linda, Calif.

Ran Goldman, MD, Hospital for Sick Children, Toronto

Niranjan Kissoon, MD, University of Florida HSC/Jacksonville, Jacksonville, Fla.

HumOUR AND HuMANITY

Jeffrey Freeman, MD, University of Michigan, Ann Arbor, Mich.

Diagnostic Challenge

Joseph Finkler, MSc, MD, University of British Columbia, Vancouver

INTERNATIONAL EM

Garth Dickinson, MD, Christ Church, Barbados

Medical Mythology

Mel Herbert, MD, University of Southern California, Los Angeles

RESIDENT IsSUES

Shelby Haque, MD, University of Alberta, Edmonton

Aaron Sibley, MD, University of Alberta, Edmonton
CJEM

Journal canadien de la médecine d'urgence

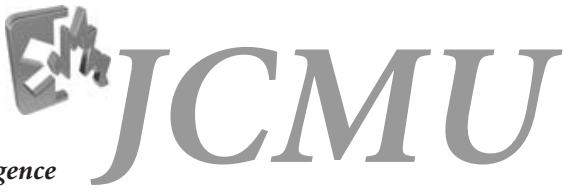

Vol. 9, No. 1, January / janvier 2007

\section{TABle OF CONTENTS • TABLE DES MATIÈReS}

\section{EDITORIAL・ÉDITORIAL}

Ruminations on a (newly indexed) journal

G. Innes

\section{ORIGINAL RESEARCH • RECHERCHE ORIGINALE}

\section{AdVANCES}

Minimally angulated pediatric wrist fractures: Is immobilization without manipulation enough?

K. Al-Ansari, A. Howard, B. Seeto, S. Yoo, S. Zaki, K. Boutis

\section{ADVANCES}

Penetrating trauma in Ontario emergency departments:

a population-based study

A.K. Macpherson, M.J. Schull

ADVANCES

Variations in monetary distribution among Ontario's Alternative Funding Agreement workload model hospitals

M. Whyne, G. Whyne, B.H. Rowe

\section{EDUCATION • ÉDUCATION}

\section{CJEM JouRnal CLUB}

Does the administration of intravenous aminophylline improve survival in adults with bradyasystolic cardiac arrest?

K.F. Hurley

Medical Mythology

Myth: Parenteral ketorolac provides more effective analgesia

than oral ibuprofen

S. Arora, J.G. Wagner, M. Herbert

Diagnostic Challenge

Is it real?; Answer

I. Grate, Jr., T. Peter

33; 60

\section{COMMENTARIES • COMMENTAIRES}

Critical care response teams: potential roles for emergency physicians

S. Upadhye, E.P. Rivers, A. Worster

Critical care response teams: A step forward in patient care, or a step closer to an emergency physician manpower crisis? J. Ducharme 
Tim Allen, MD, Quebec City

Greta Cummings, BScN, MEd, RN, PhD, Edmonton

Brian Goldman, MD, Toronto

Daniel W. Howes, MD, Kingston, Ont.

Shane Neilson, BSc, MD, Halifax

Michael J. Schull, MD, MSc, Toronto

Marco Sivilotti, MD, MSc, Kingston, Ont.

Andrew H. Travers, BSc, MD, MSc (Epidemiol), Halifax

Business And Promotion

Chris Evans, MD
University of Alberta, Edmonton cevans@ ualberta.ca

Translation / Traduction

Danielle Séguin-Tétreault, MTrad

Marketing and Advertising Sales / Marketing et publicité

Keith Comunications Inc. info@keithhealthcare.com

Toronto: 905 278-6700 or 800 661-5004; fax 905 278-4850

Montréal: 514 624-6979 or 877 761-0447; fax 514 624-6707

CJEM is owned by the Canadian Association of Emergency Physicians (CAEP) and printed by Dollco Printing, Ottawa, on acid-free stock.

CAEP Head Office: 1785 Alta Vista Dr., Ste. 104, Ottawa ON K1G 3Y6; tel 613 523-3343; fax 613 523-0190; cjem@ caep.ca

Editorial inquiries, submissions and all other correspondence: Send to CJEM, c/o Dr. Grant Innes, Dept. of Emergency Medicine, St. Paul's Hospital, 1081 Burrard St., Vancouver BC V6Z 1Y6; 604 806-8980, cjem@caep.ca

Instructions for Authors, Service Information: see Table of Contents. Address changes or requests for permission to reproduce items in CJEM: contact cjemsubscriptions@ @aep.ca

Indexed by MEDLINE/PubMed, EMBASE, CINAHL, International Pharmaceutical Abstracts (IPA), BIOME/OMNI, Scirus, Cochrane Prehospital and Emergency Health Field, and PubsHub.com.

Publications mail agreement no. 0344505499. USPS \#017-766; periodical postage paid at Champlain, NY. Return undeliverable copies to the CAEP Head Office or to IMS of NY, 100 Walnut St., \#1, PO Box 1518 Champlain NY 12919-1518. ISSN 1481-8035.

We acknowledge the financial support of the Government of Canada, through the Canada Magazine Fund, toward our editorial costs.

\section{PAAB* Canadä}

All prescription drug advertisements have been cleared by the Pharmaceutical Advertising Advisory Board.

(c) 2007 Canadian Association of Emergency Physicians Association canadienne des médecins d'urgence

\section{Publisher / Éditeur}

CJEM is published in January, March, May, July, September and November for CAEP by the Canadian Medical Association (CMA), Ottawa. CAEP and the CMA assume no responsibility or liability for damages arising from any error or omission, or from the use of any information or advice contained in the journal, including articles, editorials, case reports, reviews, media reviews, letters and advertisements. All editorial matter in CJEM represents the opinions of the authors and not necessarily those of CAEP or the CMA.

Director, Publications / Directrice, Services D'édition Glenda Proctor

EDITOR / RÉDACTRICE

Jennifer E. Raiche

800 663-7336 x2114; fax 613 565-2382; jennifer.raiche@cma.ca

\section{PRODUCTION}

Kathryn A. Freamo

Nicole Barbeau, Clara Walker

Classified Advertising / AnNonces ClasséEs

Beverley Kirkpatrick, Deborah Rodd

613 731-8610 x2127/2314; fax 613 565-7488; advertising@cma.ca

Display AdVERTising / ANNONCES PUBlicitaires

Deborah Woodman, $613731-8610$ x2159

\section{CASE REPORTS • OBSERVATIONS DE CAS}

Purulent pericarditis in a patient with rheumatoid arthritis treated with etanercept and methotrexate

D.D. Sweet, G. Isac, B. Morrison, J. Fenwick, V. Dhingra

Right subclavian catheter perforation of the aorta due to an incorrect external landmark-guided insertion technique

R. Haaverstad, P.N. Latto, N. Vitale

\section{IMAGES • IMAGES}

A rare case of penetrating knee injury by a rope

B. Petersen, W. Findlay, E.N. Vu

\section{HUMOUR AND HUMANITY • HUMOUR ET HUMANITÉ}

ACH: Career Opportunity in Emergency Medicine

A. Lund

\section{LETTERS}

Etomidate and RSI: How important is post-intubation hypotension?, R. Green; Response, M.L.A. Sivilotti

\section{News • Nouvelles}

Emergency physicians receive Who's Who in Healthcare Awards.

Emergency physician wins Giller Prize, S. Neilson.

CMA editor extraordinaire retires.

EM Research Fellowship

Call for Papers

Calendar • Calendrier

SERVICE INFORMATION • SERVICES

50

INSTRUCTIONS FOR AUTHORS • INSTRUCTIONS POUR LES AUTEURS

Classified Advertising • AnNonces Classées

53; 56

65

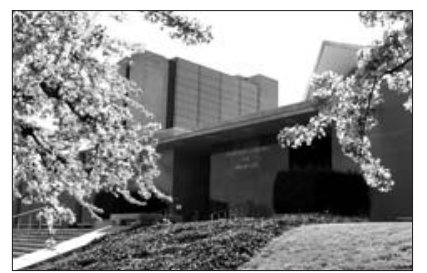

About the Cover:

Top: Main entrance, National Library of Medicine, Bethesda, Maryland.

The NLM was founded in 1836 and established on this site in 1961.

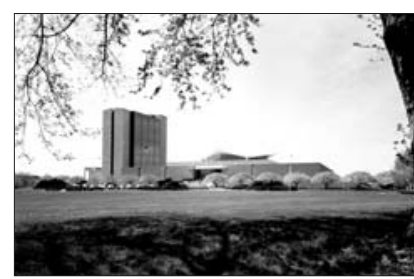

Bottom: NLM complex.

Lister Hill Center for Biomedical Communications Records on the left Why feature the NLM on our cover? See the Editorial, page 5.

Photos courtesy US National Library of Medicine

\section{ADVERTISERS' INDEX INDEX DES ANNONCEURS}

Abbott Laboratories, Limited

72, Inside Back Cover

Pfizer Canada Inc.

Lyrica Pregabalin 61, 62, 63, 64, Outside Back Cover 